\title{
Effect of Profitability and Growth Rate of Corporate Values
}

\author{
Yuni Kusuma Arumsari \\ University of Gajayana Malang, St. Mertojoyo Blok L Merjosari, Malang, Indonesia
}

Correspondence Author: Yuni Kusuma Arumsari, University of Gajayana Malang, St. Mertojoyo Blok L Merjosari, Malang, Indonesia.

E-mail:- yuni_kusuma79@yahoo.com

Received date: 15 August 2019, Accepted date: 25 October 2019, Online date: 22 November 2019

Copyright: () 2019 Yuni Kusuma Arumsari, This is an open-access article distributed under the terms of the Creative Commons Attribution License, which permits unrestricted use, distribution, and reproduction in any medium, provided the original author and source are credited.

\begin{abstract}
This study aims to examines and analyzes the effect of profitability and firm growth on firm value. This study also aims to find out more information about the profitability and growth of the company on corporate values both from the agency and simultaneously. This study used a hypothesis related to the analysis of the data examined, along with data collection techniques used were documentation. This research is the development, which is a repetition of the research study - a similar but previous studies with samples, variables, and different periods. This study also used the partial test and simultaneous test aimed to determine the effect of partial and simultaneous. Results from the study showed that the company's profitability partial effect on the value of the company with a value of $t>t$ table that is equal to $3,013>1,860$ and $s i g<0.05$, Positive $t$ value means a positive influence, if profitability increases, the value of the company will also increase. Based on that show that the more the company's profitability in the company's annual report will further enhance shareholder value. For the company's growth is partially affected by the $t$ count $>t$ table that is equal to $2,189>1,860$, this shows the influence of the growth of the value of the company. Positive $t$ value means a positive effect, namely if growth increases, the value of the company will also increase. Based on the above shows that the higher growth in the company's annual report will further enhance shareholder value. While simultaneously affect the profitability and growth of the company value. It can be seen from the analysis of variable profitability and growth of the company to the value of the company has calculated $F$ value of 22.784 while the $F$ table $(\alpha=0: 05$; regression $\mathrm{df}=2$ : residual $\mathrm{df}=7$ ) was 4.74 . Because the $\mathrm{F}$ count $>\mathrm{F}$ table is $22.784>4.74$ or the Sig. F $(0,049)<\alpha=0.05$ then regression analysis model is significant. This means that $\mathrm{HO}$ rejected and $\mathrm{H} 1$ accepted so that it can be concluded that the value of the company can be significantly influenced by the profitability and growth.
\end{abstract}

Keywords: Profitability, Growth Company, Company Value

\section{INTRODUCTION}

Currently, the food and beverage industry is growing more rapidly in Indonesia. Compared with other creative industries, the food and beverage industry even get a huge opportunity to continue to grow. Even in times of crisis though, the industry is still able to survive, while the total value of exports of food and beverages in 2008. Amounted to USD 2 million. In 2008, the turnover of the industry was almost $\mathrm{Rp} 400$ trillion. Competition in the emerging demands of an enterprise to further improve performance and to innovate with product - a product that has to be more recognized again by the public. To improve performance and innovate to introduce their products to the public, then the company needs more funding. Companies desperately need additional capital to boost the company's operational performance. (Source:www.kontan.co.id)

The main purpose of publicly listed companies is enhancing the prosperity of the owners or shareholders by increasing the value of the company, Hermuningsih(2013:128). Opportunities to invest in the food and beverage sector is auspicious, because the market is still wide open with a large population as well. "The turnover of enterprises of food and drinks will reach Rp360 trillion by the end of 2008," said Chairman of the Association of Food and Beverage Association (GAPMMI) Thomas Darmawan in Jakarta, Monday (07/21/2008). Based on data from the Central Statistics Agency (BPS), the import value of food and beverages on until September 2008 is estimated to reach US \$ 2,24miliar ranks third compared to the sector - other sectors.(Source: www.indocashregister.com)

One mirror of economic growth is the growth of capital markets. Indonesia's economic growth is also reflected in the performance of the Composite Stock Price Index (CSPI), which increased quite significantly since 2002. Within the last 10 years JCI surge by $874.90 \%$. At the end of 2002, namely the closure of the last trade on December 27th JCI closed at 424.95, while the 
per December 30, 2011, Composite Index closed at 3,821.99. However, in 2008 CSPI decreased by 50.64\% YoY ie, is the impact of the economic crisis that hit the United States and most developed countries.

The stock market price is one indicator of how the market is valuing the company as a whole. Stock is one instrument of the most popular financial markets, stocks also an investment that has been chosen by the investors because it can provide attractive benefits.According to Nafarin (2007: 788) "Profit (income) is the difference between the revenues with the balance of costs - fees and expenses for a specific period". According to Halim \& Supomo (2005; 139)"Profit is the responsibility centres that input and output are measured by calculating the difference between revenues and costs". According Kuswadi (2005: 135), states that "The calculation of earnings derived from revenue minus all costs". According to Hanafi (2010: 32), states that "Profit is the overall size of the achievements of the company, which is defined as follows: Profit = Sales-Cost".

According to Ika and shidiq (2013), the value of the company is value reflects how much investors are willing to pay for a company. High stock prices make the company's value too high. Maximizing the value of the company is very important for a company because by maximizing corporate value means also maximizes prosperity shareholders, who are the main objectives of the company.

Viewed from the phenomenon occurs that the food and beverage sector has decreased in 2008. Therefore it is necessary to research related to the effect of profitability and growth rates of the value of the company, especially in Food and Beverages Listed in Indonesia Stock Exchange (IDX) Period of 2007-2011.

\section{LITERATURE REVIEW}

\section{Capital structure}

What is the deciding factor of the company's capital structure? In the field of corporate finance, a lot of researchers have spent time both theoretically and empirically to answer this question. After their publication by Modigliani and Miller (1963), this question has gained special significance. The determinants of capital structure have been investigated by several researchers. However, there is still no unifying theory of capital structure even after several decades of research that very seriously, which makes the topic of open capital structure for further study. The capital structure is basically a mix of debt and equity used to finance the company's assets.

Modigliani and Miller (1958) first give the concept of capital structure. They argued that the capital structure has the power to change the value of a company. This theory is based on several assumptions: No taxes, no transaction fees, no bankruptcy costs and market information symmetry. MM expand their theory in 1963 and assuming no tax release. As a result of the theory of MM (1958) developed the theory of trade-offs that elaborates companies that focus on debt financing and saved the company from taxes. Myers (1977) presents the pecking order theory. This theory believes that the company took the finance from external sources such as equity rather than debt. Jensen and Meckling (1976) devised a method that explains the agency costs of debt and equity.

There are several theories used in this research mainly specialized on the capital structure of which is the trade-off theory, pecking order theory, agency theory and views of Islam associated with the capital structure of Islamic banking.

\section{Trade-Off Theory}

Trade-off theory put forward by Modigliani and Miller (1963) explains that the level of the most favourable capital structure can be determined by balancing the benefits and costs associated with debt financing. It would be more like a balance between the tax shield on interest expense and costs associated with the financial burden. Trade-off theory of capital structure expects that organizations with better profitability should choose to use debt financing rather than equity financing to take advantage of the tax shield.

According to Baxter (1967), taxes, agency costs, and financial difficulties are the three main factors that affect the optimal capital structure of the company according to the theory of trade-offs. The company will use a large amount of debt in its capital structure for debt gives them protection against taxes, increase their profitability. However, the use of higher debt would increase the cost of losses. Thus, creditors will demand an additional risk premium which increases the cost of debt.

\section{Pecking Order Theory}

Pecking order theory put forward by Myers and Majluf (1984) and Myers (1984) stated that the capital structure of the company is the result of the financing requirements of the company from time to time and effort to minimize the problem of selection are considered harmful. Pecking order theory provides a ranking of the sources of financing based on the level of which is influenced by asymmetric information. In this case, the company prioritizes internal funds rather than equity. In other words, the pecking order theory is mainly based on the idea of asymmetric information between insiders and outsiders as well as the results of adverse selection problems.

\section{Agency theory}

Through Home Visits agency explained that the capital structure is the result of efforts of managers to minimize the costs associated with the separation of management and control (Jensen \& Meckling, 1976). Managers have incentives to maximize the equity value rather than the value of the company. In particular, project managers tend to engage in risky and even project net present value (NPV) were negative. In the case of a successful project, this effort will benefit shareholders as the benefits of this project to grow for shareholders. However, in case of failure, debt holders will bear the loss. Because the debt is too risky, debt holders will demand a risk premium and ultimately higher interest payments as compensation for risky projects. This behaviour 
follows the same reasons as Myers' (1977) hypothesis of under-investment. Evidence suggests that managers of companies with high leverage have an incentive not to project positive NPV for-profits accrue to bondholders.

An agency relationship arises because the delegation of responsibility in the decision of the principal to the agent, the agent relationship of these cases could create unfairness information (information asymmetry). Information asymmetry occurs when one group or the manager has information that is better or more timely than other groups in the company (Ballwieser et al., 2012). So, it can open up opportunities for the manager (agent) to act opportunistically as seeking personal gain. Meanwhile, the principal will have difficulty in controlling agent, because, the principal has less firm information from the agent. Therefore, in the management of the company,

The core of the agency relationship is the separation of functions between ownership and control in the administration. The separation between the business owners and management by the management agency is likely to cause a conflict between principal and agent. Conflicts of interest between principal and agent occur because the agent may not always act in accordance with the wishes of the principal, causing the cost of the institution (agency cost). According to Jensen and Meckling (1976) in Masdupi (2005) agency costs include three things, namely monitoring costs, bonding costs and residual loss. Monitoring costs are fees paid by the head to measure, observe and control the behavior of agents in order not to deviate. These costs arise because of the imbalance of information between principal and agent. In certain situations, agent's possible to spend company resources (bonding costs) to ensure that the agency will not act that may be detrimental to the principal or to ensure that the principal will provide compensation if he is actually doing the act. But there may occur a difference between the agent's decision with the decision to maximize the welfare of the institution. Value for money is equivalent to the reduction of welfare experienced by perpetrators of so-called residual losses.

\section{Factors capital structure}

This section includes literature that emphasizes the determinants of capital structure of Islamic banking. In the context of the CB, few studies have investigated the determinants (Caglayan \& Sak, 2010; Frank and Goyal, 2009; Gropp \& Heider, 2010). According to this literature, there is an essential relationship between the company's capital structure with different factors, namely the size of the company, profitability, tangibility, growth opportunities and dividend policy. Study Frank and Goyal (2009), however, made some crucial contributions to defining factor of capital structure, the so-called "core models of leverage" or leverage core model. Table 4 below shows the predictions of the theory of a trade-off and pecking order theory related to the relationship between leverage and factors.

Table 3. Factors of Capital Structure

\begin{tabular}{|c|c|c|c|}
\hline No. & determinant & The theory of trade-offs & theory pecking \\
\hline $\mathbf{1}$ & Company size & + & - \\
\hline $\mathbf{2}$ & profitability & + & - \\
\hline $\mathbf{3}$ & tangibility & + & - \\
\hline $\mathbf{4}$ & growth opportunities & - & $-/+$ \\
\hline
\end{tabular}

Source: Frank and Goyal (2009)

Based on the above table shows that the positive sign "+" indicates that the variable has a positive relationship with leverage. The negative sign '-' indicates a negative relationship between the variables and leverage.

\section{Profitability}

Profitability is the ability of a company to make profits through its business operations by using fund assets owned by the company. Profitability is the end result of a number of policies and management decisions of firms Brigham and Gapenski (2006). Thus it can be said that the profitability of the company is a company's ability to generate net income from activity undertaken in an accounting period. Profitability according to Saidi (2004) in Martalina (2011) is the company's ability to earn income.

In practice, according to Kashmir (2008: 199) type - the type of profitability ratio that can be used are:

1) Profit margin (profit margin on sales)

2) Return on Assets (ROA)

3) Return on equity (ROE)

4) Earnings per share.

\section{Company growth}

Growth due to the influence of climate and local business situation and business climate If the infrastructure to support these efforts, the company will look good pertubuhan from time to time. According to Pradana (2013), the measuring instrument for the growth of the company there are two, namely:

(1) Assets Growth Ratio

Assets Growthshows the growth of assets in which the asset is an asset that is used for the operating assets of the company.

The greater the greater the asset expected operating results generated by the company. 


\section{(2) Sales Growth Ratio}

Pradana (2013), argued that sales growth is a change in sales per year. High sales growth gives an indicator of the company concerned could increase his company's growth and is expected to increase the profit generated.

\section{The value of the company}

The company's value reflects the current value of the future income desired and indicators for the market in assessing overall company Christiawan and Tarin (2007). Some proxies are used to measure the value of the company include:

1) Price Earning Ratio (PER) By Usman in Kusumaningrum (2013), PER is the ratio that measures how much of a comparison between the company's stock price gains of the shareholders. Factors that affect the PER is:
a) The growth rate of profit
b) Dividend Payout Ratio
c) The rate of profit required by financiers

2) Price Book Value (PBV) This ratio measures the value given to the management of financial markets and corporate organizations as a company that continues to grow (Brigham, 1999, in Wahyudi and Pawestri, 2006).

\section{hypothesis}

H1: Profitability has an influence on the company's Corporate Value food and beverage.

H2: Growth companies have an influence on the value of the company at the company's food and beverages.

\section{RESEARCH METHODS}

This research is explanatory research with a quantitative approach. The object of this study is the Food and Beverage companies listed in Indonesia Stock Exchange (IDX) in the period 2007 to 2011 the company became a sample of 10 companies conducted by purposive sampling.

\section{Operational Definition of Variables}

a. X1 variable in this study is the profitability (profitability) in this study was measured by using a ratio - the ratio of profitability, namely:

1) Return on Assets (X1.1) is a measurement of the ability of the company's overall profit in the total amount of assets available within the company. The higher this ratio, the better the state of a company Shamsuddin (2007: 63).

2) Return on Equity (X1.2) is a measurement of earnings (income) available to the owners of the company (both common shareholders and preferred shareholders) on the capital that they invested in the company. In general, of course, the higher the return or revenue earned, the better the position of the company owner Shamsuddin, (2007: 64).

3) Operating profit margin

(X1.3). This ratio describes what is usually called "pure profit" earned on every penny of the sales made. Operating profit is called pure (pure) in the sense that the number is exactly right - it is obtained from the company's operating results by ignoring liabilities - financial liabilities in the form of interest and obligations to the government in the form of tax payments. The higher the ratio of operating profit margin, the better it is operating a company Shamsuddin (2007: 61).

b. X2 in this study are Growth or pertummbuhan level. The growth rate (growth) in this study was measured using the following indicators:

1) assets growth (X2.1), describes the increase or decrease in the company's assets every year.

2) Sales growth (X2.2), Describes the increase or decrease in sales each year. The higher level of sales of a company's growth will rely more on external capital. A company with high sales growth tend to be more use of debt (bonds) compared with companies that have a slow growth rate.

c. Y variables in this study are the value of the company. The company's value is a measure of the success of the company's management in past operations and future prospects to convince shareholders (Mas'ud, 2008). In search of an alternative value of the company on certain capital structure, the company is looking for a rate of return that must be obtained as compensation for investors and owners on the risks that will bear.

The company's value is measured using indicators - indicators as follows:

1) Price Earning Ratio (Y2.1)

Is the ratio that indicates the ratio between the price per share (price per share) to earnings per share (earnings per share). This ratio indicates how much investors are willing to pay per rupiah reported earnings Moeljadi (2006: 75).

\section{Methods and Data Analysis Techniques}

The method is the classical assumption which classical assumption is testing assumptions - assumptions that must be met in preparing the regression that results are not biased Suhardi \& Purwanto (2004: 628). Data were analyzed using multiple linear regression analysis. Test the hypothesis using the $\mathrm{F}$ test for simultaneous effect and the $\mathrm{t}$-test for the partial effect.

\section{RESEARCH RESULT}

Testing data using SPSS v. 21 shows that all variables used item has been tested and meets the classical assumption. Normality Test based on the Kolmogorov-Smirnov test on the table, for the analysis of independent variables on the dependent, has a significant value of 0.241 , where the value is greater than a $=0.05$. Autocorrelation test has been tested and the results to all 
regression models Durbin Watson value is between values du and $4-\mathrm{du}(\mathrm{dU}<\mathrm{d}<4-\mathrm{dU})$, so it can be determined that the data is not autocorrelation and to test multikolinieritas can be demonstrated that the value of tolerance is less of 1 and VIF is less than 10,

\section{Results of Multiple Linear Regression Analysis}

Multiple regression analysis is used to determine the effect of profitability variable (X1), the company's growth (X2), to variable enterprise value $(\mathrm{Y})$.

Table 4

Results of Multiple Linear Regression Analysis

\begin{tabular}{|c|c|c|c|c|}
\hline \multicolumn{2}{|c|}{ Model } & Coefficients unstandardized & \multirow{2}{*}{ T } & \multirow{2}{*}{ Sig. } \\
\cline { 3 - 5 } & beta & & \\
\hline \multirow{3}{*}{1} & Constant) & 27.413 & 3,168 &, 000 \\
\cline { 2 - 5 } & Profitability &, 319 & 3,013 &, 003 \\
\cline { 2 - 5 } & Growth &, 615 & 2,189 &, 042 \\
\hline
\end{tabular}

Sources: Primary data is processed, 2018

Based on Table 1 above the obtained regression equation:

$Y=(27413)+0,319 X 1+0,615 X 2$

a. The regression coefficient profitability variable (X1) is approximately 0.319 which shows that the profitability variable (X1) has the effect of forecasting of trends or positively impact the company's value (Y). This means that any increase of profitability (X1) as much as $1 \%$, there will be an increase in the enterprise value (Y) of $0.319 \%$.

b. The regression coefficient growth variables (X2) is approximately 0.615 which shows that the growth variable (X2) has the effect of forecasting of trends or positively impact the company's value (Y). This means that each increment of growth (X2) as much as $1 \%$, there will be an increase in the enterprise value (Y) of $0.069 \%$.

\section{Hypothesis testing}

a. The first hypothesis test in this study was tested using the t-test. The test results using SPSS generates the following data:

Table 5:t-test
\begin{tabular}{|c|c|c|c|c|}
\hline \multirow{2}{*}{ Model } & Coefficients unstandardized & \multirow{2}{*}{$\mathrm{t}$} & \multirow{2}{*}{ Sig. } \\
\cline { 2 - 3 } & Beta & & \\
\hline \multirow{3}{*}{1} & (Constant) & 27.413 & 3,168 &, 000 \\
\cline { 2 - 5 } & profitability &, 319 & 3,013 &, 003 \\
\cline { 2 - 5 } & Growth &, 615 & 2,189 &, 042 \\
\hline
\end{tabular}

Sources: Primary data is processed, 2018

Influence the profitability of the value of the company has amounted to 3,013 $\mathrm{t}$ with a significance of 0.003 . $\mathrm{T}$ value greater than $t$ table which amounted to $1,860(3,013>1,860)$, this shows the influence of profitability on firm value. Positive count $t$ value means a positive impact, yatu if profitability increases, the value of the company will also increase. The significant value of 0.003 , less than 0.05 , so the decision to $\mathrm{H} 0$ is rejected. It can be concluded that profitability had a significant impact on the value of the company.

The growing influence of the value of the company has $\mathrm{t}$ by 2189 with a significance of 0.042 . $\mathrm{T}$ value greater than $\mathrm{t}$ table which amounted to $1,860(2,189>1,860)$, this shows the influence of the growth of the value of the company. Value positive $t$ value means a positive effect, namely if growth increases, the value of the company will also increase. The significance value of 0.042 , less than 0.05 , so the decision to $\mathrm{H} 0$ is rejected. It can be concluded that growth has a significant impact on the value of the company.

b. The second hypothesis test using the F test as the test tool. The test results with SPSS generate the following data:

Table 6:test F

\begin{tabular}{|c|c|c|c|c|c|}
\hline Model & Sum of Squares & df & mean Square & F & Sig. \\
\hline Regression & 2973.390 & 2 & 1486.695 & 22.784 &, 049 \\
\hline Residual & 15161.126 & 8 & 1895.141 & & \\
\hline Total & 18134.516 & 10 & & & \\
\hline
\end{tabular}

Sources: Primary data is processed, 2017

Based on Table 3 calculated $F$ value of 22.784 while the $F$ table $(A=0: 05$; regression $\mathrm{df}=2:$ residual $\mathrm{df}=7)$ was 4.74 . Because the F count $>$ F table is $22.784>4.74$ or the Sig. F $(0,049)<\alpha=0.05$ then regression analysis model is significant. This means that $\mathrm{H} 0$ rejected and $\mathrm{H} 1$ accepted so that it can be concluded that the dependent variable (the value of the company) can be significantly influenced by the profitability of the independent variable (X1) growth (X2).

\section{DISCUSSION}


This study uses profitability as the independent variable and the value of the company as the dependent variable. In the first hypothesis (H1) stated that profitability has an influence on the value of the company. Based on the test results of H1 on Partial Test $(\mathrm{t})$, the study found the influence of profitability on firm value. Variable profitability on the company's value had amounted to $3,013 \mathrm{t}$ with a significance of 0.003 . T value greater than $t$ table which amounted to $1,860(3,013>1,860)$, this shows the influence of profitability on firm value. Value positive $t$ value means a positive influence, yatu if profitability increases, the value of the company will also increase. The significant value of 0.003 , less than 0.05 , so the decision against H0 is rejected. It can be concluded that profitability had a significant impact on the value of the company.

The results are consistent with the hypothesis proposed in H1 so that H1 in this study received. It is also in line with research that has been done by Mardiyati (2012), Setiabudi and Dian (2012), Rizqia et al, (2013) that the profitability has a positive effect on firm value. It is also be reviewed from the theory proposed by Amirya and Atmini (2007) in Lifessy (2011) that the profitability is one of the factors that influence the value of the company. This study wanted to test the effect of profitability on the value of the company at different periods. The result can be concluded that in line with previous studies that affect the profitability of the company's value.

Based on the above results, the more the disclosure of the company's profitability in the company's annual report will further enhance shareholder value. Their profitability is getting better enhance the reputation and value of a company so that it can attract investors or the existence of good relations between the company and outside parties,

\section{Influence on Corporate Value Growth in Food and Beverages.}

This study uses growth as an independent variable and the value of the company as the dependent variable. In Hypothesis 2 (H2) suggests that growth companies have an influence on the enterprise value of the company. Based on the test results of $\mathrm{H} 2$ at partial test $(\mathrm{t})$, the study found the influence of the company's growth on firm value. Based on the test results of $\mathrm{H} 2$ at partial test $(t)$, the study found the influence of the company's growth on firm value. Variable growth of the value of the company has amounted to $2,189 \mathrm{t}$ with a significance of 0.042 . T value greater than $\mathrm{t}$ table which amounted to $1,860(2,189>1,860)$, this shows the influence of the growth of the value of the company. Positive count $t$ value means a positive effect, namely if growth increases, the value of the company will also increase. The significance value of 0.042 , less than 0.05 , so the decision to H0 is rejected. It can be concluded that growth has a significant impact on the value of the company.

The results of this study are also consistent with the hypothesis proposed that the H2, H2 empirically so that it is received. In line with the research that has been done by Afrida (2008) found that the growth of the company has a direct influence and positive impact on stock price changes, which means that information about their company's growth responded positively by investors, thereby increasing the share price and will indirectly increase the value company. Equality of outcome in this study due to the look of the growth in sales and assets so that they can measure how much growth the company to increase the value of the company.

Based on the above results, indicating that the company experienced growth in sales and assets which have been disclosed in the annual report of the company, is able to increase the value of the company. Results of $\mathrm{H} 2$ showed that the growth of the company can increase the value of the company so that the value of the company with the acquisition of shares and a positive response from investors will increase along with the growth of the company.

\section{Influence the Profitability and Growth of the Company Value in Food and Beverages.}

This study uses the profitability and growth of the company as an independent variable and the value of the company as the dependent variable. Hypothesis 3 (H3) said the profitability and growth of the company has a simultaneous effect on firm value. Based on the test results of H3 on Simultaneous Test $(F)$, the study found their simultaneous effect on firm value. Variable profitability and growth of the company have calculated $\mathrm{F}$ value of 22.784 while the $\mathrm{F}$ table $(\alpha=0: 05$; regression $\mathrm{df}=2$ : residual $\mathrm{df}=7$ ) was 4.74 . Because the F count $>\mathrm{F}$ table is $22.784>4.74$ or the Sig. F $(0,049)<\alpha=0.05$ then regression analysis model is significant.

The results are consistent with the hypothesis that $\mathrm{H} 3$, thus $\mathrm{H} 3$ in this study received. This study was able to show evidence of the effect of profitability and growth of the company simultaneously against the value of the company. In line with research conducted by Susanti (2010) and Afrida (2008) that the profitability and growth of the company has an influence on the value of the company.

The results showed that the profitability and growth of the company have the same influence on corporate value, due to the disclosure of profits and sales growth as well as a maximum of the company's assets, so investors interested to invest in companies because of the value of a good company. Investors can weigh in a decision by the results of the profitability and growth of the company. So with the increasing value of the company were reviewed by the profitability and growth of the company is good, then investors are ready to invest in the company and make the significant increase in the value of the company.

\section{CONCLUSION AND SUGGESTION}

\section{Conclusion}

a. This study proves that the company's profitability significantly positive effect on firm value. It can be seen from the analysis of the profitability variable to the value of the company has amounted to 3,013 t with a significance of 0.003 . $T$ value greater than $t$ table which amounted to $1,860(3,013>1,860)$, this shows the influence of profitability on firm value. Positive $t$ value means a positive influence, if profitability increases, the value of the company will also increase. Based on that show that the more the company's profitability in the company's annual report will further enhance shareholder value. 
b. This study proves that the company's growth significant positive effect on firm value. It can be seen from the analysis of the company's growth variable to the value of the company has amounted to 2,189 $\mathrm{t}$ with a significance of 0.042 . $\mathrm{T}$ value greater than t table which amounted to 1,860 (2,189> 1,860), this shows the influence of the growth of the value of the company. Value positive $t$ value means a positive effect, namely if growth increases, the value of the company will also increase. Based on the above shows that the higher growth in the company's annual report will further enhance shareholder value.

c. This study proved that the profitability and growth of the company have simultaneously effect on firm value. It can be seen from the analysis of variable profitability and growth of the company to the value of the company has calculated $\mathrm{F}$ value of 22.784 while the $\mathrm{F}$ table $(\alpha=0: 05$; regression $\mathrm{df}=2$ : residual $\mathrm{df}=7)$ was 4.74 . Because the $\mathrm{F}$ count $>\mathrm{F}$ table is $22.784>4.74$ or the Sig. F $(0,049)<\alpha=0.05$ then regression analysis model is significant. This means that H0 rejected and H1 accepted so that it can be concluded that the value of the company can be significantly influenced by profitability and growth.

\section{Suggestion}

a. The researcher then expected to use the additional variable of profitability and growth that research results can be widespread.

b. Further research is expected to analyze the profitability and growth of the company deeper than the source - the source of more complete.

\section{BIBLIOGRAPHY}

Abdul Muid, Moch. Ronni Noerirawan. 2012. Pengaruh Faktor Internal dan Eksternal Perusahaan Terhadap Nilai Perusahaan (Studi Empiris Pada Perusahaan Manufaktur Yang Terdaftar Di Bursa Efe k Indonesia Periode 2007-2010). Jurnal Akuntansi Volume 1 No.2Hal. 4

Amirya, MirnadanAtmini Sari. (2007). Faktor-faktor yang mempengaruhinilaiperusahaan yang dimediasioleh leverage sebagai variable intervening :sebuahperspektif Pecking Order Theory. The 1 Accounting conference faculty of economic Universitas Indonesia, Depok 7-9 November 2007.

Ansori, Mokhamat dan H. N. Denica. 2010. Pengaruh Keputusan Investasi Keputusan Pendanaan dan Kebijakan Dividen Terhadap Nilai Perusahaan pada Perusahaan yang Tergabung dalam Jakarta Islamic Index Studi pada Bursa Efek Indonesia (BEI). Analisis Manajemen, ISSN: 1411-1799, Vol. 4, No. 2 (Juli), Hal. 153-175.

Akhtar, Muhammad F, et. al. 2011. Factors Influencing the Profitability of Islamic Banks of Pakistan. International Research Journal of Finance and Economics.

Baxter, N.D. (1967). Laverage, risk of ruin and the cost of capital, journal of finance, September, 395-403.

Ballwieser, W., Bamberg, G., Beckmann, M. J., Bester, H., Blickle, M., Ewert, R., Feichtinger, G., Firchau, V., Fricke, F., Funke, H., and others. 2012. Agency theory, information, and incentives, Springer Science \& Business Media.

Brealey, Myers, Marcus. 2008. Dasar-Dasar Manajemen Keuangan. Edisi 5 Jilid 1. Jakarta : Erlangga

Bilal, Muhammad, et, al. 2013. Influence of Bank Specific and Macroeconomic Factors on Profitability of Commercial Banks: A Case Study of Pakistan. Research Journal of Finance and Accounting. Vol.4, No.2

Brigham, E.F. dan L.C. Gapenski. 2006. Intermediate Financial Management. 7th edition. Sea harbor Drive: The Dryden Press, New York.

Caglayan, E., \& Sak, N. (2010). The determinants of capital structure: evidence from the Turkish banks. Journal of Money, Investment and Banking, 15(June 2016), 57-65.

Christiawan, Yulius Jogi dan Josua Tarigan. 2007. Kepemilikan Manajerial: Kebijakan Hutang, Kinerja dan Nilai Perusahaan. Jurnal Akuntansi dan Keuangan, Vol. 9, No.1.

D., Prastowo Dwi dan Rifka Juliaty. 2008. Analisis Laporan Keuangan: Konsep dan Aplikasi (Edisi Kedua). Yogyakarta: UPP STIM YKPN.

Dewa, kadek\& Kusumajaya. 2011. Pengaruh struktur modal dan pertumbuhan perusahaan terhadap profitabilitas dan nilai perusahaan.Jurnal Akuntansi.

Dewi, Putu Yunita Saputri, dkk. 2014. "Pengaruh Struktur Modal, Pertumbuhan Perusahaan terhadap Nilai Perusahaan pada Perusahaan LQ45 di BEI Periode 2008-2012”. E-journal S1 AK Universitas Pendidikan Ganesha. Vol.2 No.1. Universitas Pendidikan Ganesha. Bali: Universitas Pendidikan Ganesha

DJ, Alfredo Mahendra et, al. 2011. Pengaruh Kinerja Keuangan Terhadap Nilai Perusahaan (Kebijakan Dividen Sebagai Variabel Moderating) Pada Perusahaan Manufaktur Di Bursa Efek Indonesia. Tesis. Bali. Universitas Udayana.

Eduardus, Tandelilin. 2001. "Analisis Investasi dan Manajemen Risiko". Edisi Pertama. Yogyakarta:BPFE.

Frank, M. Z., \& Goyal, V. K. (2009). Capital structure decisions: Which factors are reliably important? Financial Management, $38(1), 1-37$.

Fanindya, Ika \& Nur, Shiddiq. 2013. Analisis Pengaruh Profitabilitas, Kebijakan Deviden, Kebijakan Utang, dan Kepemilikan Manajerial Terhadap Nilai Perusahaan (Studi Empiris pada Perusahaan Manufaktur yang Terdaftar di Bursa Efek Indonesia Periode 2009 - 2011). Undergraduate thesis.Fakultas Ekonomika dan Bisnis Universitas Dipenegoro.

Gropp, R., \& Heider, F. (2010). The determinants of bank capital structure. Review of Finance, 14(4), 587-622.

Gul, S., Irshad, F., \& Zaman, K. 2011. Factors Affecting Bank Profitability in Pakistan. The Romanian Economic Journal, 39, 6187.

Ghozali, Imam. 2013. Aplikasi Analisis Multivariate dengan Program IBM SPSS 21 Update PLS Regresi. Semarang: Badan Penerbit Universitas Diponegoro.

Gallagher, Timothy J. and Joseph D. Andrew Jr, 1999. Financial Management: Principlesand Practice. Penerbit Prentice Hall Inc, Ney Jersey. 
Gitman, Lawrence. 2006. Principles of Manajerial Finance. United States: Pearson Addison Wesley.

Gultom, C. M. dan F. Syarif. 2009. Pengaruh Kebijakan Leverage, Kebijakan Deviden, dan Earning Per Share Terhadap Nilai Perusahaan. Jurnal Akuntansi 47.

Hafeez, M., et al. (2018). Impact of Capital Structure on Islamic Banks Performance: (Evidence from Asian Country). Global Journal of Management and Business Research. Volume 18 Issue 3

Halim, Abdul dan Supomo, 2005. Akuntansi Manajemen, Edisi 1, Cetakan Kesebelas, BPFE, Yogyakarta.

Hartanti, Puji. 2014. Analisis Rasio Likuiditas, Rasio Leverage dan Rasio Profitabilitas Terhadap Price To Book Value. Skripsi. Surakarta: Universitas Muhammadiyah Surakarta.

Hasnawati, S. 2005. Implikasi Keputusan Investasi, Pendanaan, dan Dividen Terhadap Nilai Perusahaan Publik di Bursa Efek Jakarta. Usahawan: No. 09/Th XXXIX. September 2005: 33-41.

Harmono. 2011. Manajemen Keuangan Berbasis Balanced Scorecard Pendekatan Teori, Kasus, dan Riset Bisnis, Edisi kesatu. Jakarta: Bumi Aksara.

Hermuningsih, S. 2013. Pengaruh Profitabilitas, Growth Opportunity, Struktur Modal Terhadap Nilai Perusahaan Pada Perusahaan Publik di Indonesia.

Helfert, Erich. 2000. Techniques of Financial Analysis: A Guide to Value Creation 10th Edition. McGraw - Hill.

Husnan, Suad. 2001. Dasar - Dasar Teori Portofolio dan Analisis Sekuritas. Yogyakarta. Penerbit : UPP AMP YKP

Husnan, Suad. Dan Enny Pudjiastuti, 2004. Dasar-Dasar Manajemen

http://nasional.kontan.co.id/news/industri-makanan-dan-minuman-kebal-krisis\&prev=search. Diakses pada tanggal 18 Februari 2018

Irawati, Susan. 2006. Manajemen Keuangan. Cetakan Kesatu. Bandung: PT.Pustaka.

Ismiyanti \& Hanafi, Mahfud. 2010. Manajemen Keuangan. Cetakan ke Lima. Yogyakarta : BPFP

Indriantoro dan Bambang. 2009. Metodologi Penelitian Bisnis untuk Akuntansi \& Manajemen (Edisi 1). Penerbit : BPFE Yogyakarta

Jensen, M. C., \& Meckling, W. H. (1976). Theory of the Firm: Managerial Behavior, Agency costs and Ownership Structure. Journal of Financial Economics, 3, 305-360.

Masdupi, 2005." Analisis Dampak struktur kepemilikan pada Kebijakan Hutang dalam Mengontrol Konflik Keagenan.” Jurnal Ekonomi Bisnis vol.20, No.1. Desember .56-69.

Modigliani, F., \& Miller, M. H. (1958). The Cost of Capital, Corporation Finance and the Theory of Investment. The American Economic Review, 48(3), 261-297.

Modigliani, F., \& Miller, M. H. (1963). Corporate Income Taxes and the Cost of Capital: A Correction. The American Economic Review, 53(3), 433-443.

Myers, S. C. (1977). Determinants of corporate borrowing. Journal of Financial Economics, 5(2), 147-175.

Myers, S. C., \& Majluf, N. S. (1984). Corporate financing and investment decisions when firms have information that investors do not have. Journal of Financial Economics, 13(2), 187-221.

Keuangan Empat, Yogyakarta: UPP STIM YKPN

Kasmir, Dr. 2008. Analisis laporan keuangan. Edisi 1-5, Jakarta: Rajawali Pers.

Kuswadi. 2005.Cara Mudah Memahami Angka dan Manajemen Keuangan Bagi Orang Awam. Penerbit : Gramedia, Jakarta.

Kusumaningrum, D. A. dan S. N. Rahardjo. 2013. Pengaruh Keputusan Investasi, Keputusan Pendanaan, Kebijakan Deviden, dan Kepemilikan Manajerial Terhadap Nilai Perusahaan. Diponegoro Journal of Accounting. Vol. 2, No. 4, pp. 1-10. ISSN (online) : 2337-3806.

Lifessy. M. 2011. Pengaruh Profitabilitas dan Ukuran Perusahaan Terhadap Nilai Perusahaan Dengan Struktur Modal Sebagai Variabel Intervening. Skripsi Akuntansi Fakultas Ekonomi Universitas Negeri Padang.

Martalina, Lifessy. 2011. "Pengaruh Profitabilitas dan Ukuran Perusahaan Terhadap Nilai Perusahaan dengan Struktur Modal sebagai Variabel Intervening". Skripsi Akuntansi Fakultas Ekonomi Universitas Negeri Padang.

Martani, Dwi \& Ronald. 2009. Factors Affecting Profitability of Multi-finance Company in Indonesia. jurnal Universitas Indonesia.

Mamduh M. Hanafi dan Abdul Halim. 2003. Analisis Laporan Keuangan. Edisi Kedua. Yogyakarta : UPP AMP-YKPN.

Mardiyati, Umi, dkk. 2012. "Analisis Pengaruh Kebijakan Dividen, Kebijakan Hutang dan Profitabilitas Terhadap Nilai Perusahaan Pada Perusahaan Manufaktur Yang Terdaftar di Bursa Efek Indonesia Periode 2005-2010". Jurnal Riset Manajemen Sains Indonesia (JRMSI), Vol. 3, No. 1.

Moeljadi. 2006.Manajemen Keuangan Pendekatan Kuantitatif dan Kualitatif. BPFE: Yogyakarta.

Mas'ud, Masdar. 2008. “Analisis Faktor-faktor yang Mempengaruhi Struktur Modal dan Hubungannya Terhadap Nilai Perusahaan." Manajemen dan Bisnis, vol. 7 no. 1. Universitas Muslim Indonesia.

Mc Eachern, William A. 2000. Ekonomi Makro : Pendekatan Kontenporer Edisi 1. Diterjemahkan oleh Sigit T. Jakarta. Salemba Empat.

Nafarin. M. 2007. Penganggaran Perusahaan. Edisi ke 3. Jakarta :Salemba 4.

Pradana, H. R. dan F. Kiswanto. 2013. Pengaruh Risiko Bisnis, Struktur Aset, Ukuran, dan Pertumbuhan Penjualan terhadap Struktur Modal. Accounting Analysis Journal 2(4).

Rizqia, D. A., dkk. 2013. "Effect of Managerial Ownership, Financial Leverage, Profitability, Firm Size, and Investment Opportunity on Dividend Policy and Firm Value". Research Journal of Finance and Accounting. Vol. 4(11), hal 120-130.

Ross, S.A. 1977. "The Determination of Finacial Structure:The Incentive Signalling Approach".Journal ofEconomics. Spring, 8, pp 23-40. 
Robert C. Fink and Ann Harrison, 1999. Businaess Return on Assets, Journal of Return On Investment, Computerworld; Jun 21; vol 33, Iss 25.

Sartono, Agus. 2001. “Manajemen Keuangan Teori dan Aplikasi”. Edisi Empat. BPFE; Yogyakarta.

Santoso, Singgih. 2001. Mengolah Data Statistik Secara professional. Jakarta.

Sanusi,Anwar. 2011. Metodologi Penelitian Bisnis. Jakarta. Salemba empat.

Setiabudi, Andi, dan Dian Agustia. 2012. Fundamental factors of firm value. Journal of basic and applied scientific research.

Susanti, Rika. 2010. Analisis Faktor-Faktoryang Berpengaruh terhadap NilaiPerusahaan(Studi Kasus padaPerusahaan Go Public yang ListedTahun 2005-2008). Skripsi Universitas Dipenegoro.

Srairi, S. 2009. A comparison of the profitability of Islamic and conventional banks: The case of GCC countries. Bankers, Markets \& Investors. 98, 16-27.

Syamsudin, Lukman. 2004. Manajemen Keuangan. Penerbit : Raja Grafindo Persada, Jakarta.

Sugiyono. 2011. Metode Penelitian Kuantitatif, Kualitatif dan R\&D. Bandung: Afabeta.

Sugiyono. 2008. Metode Penelitian Bisnis. Alfabeta : Bandung.

Suhardi dan Purwanto. 2004. Statistika Untuk Ekonomi dan Keuangan Modern. Jakarta: Salemba Empat

Wahyudi, U., dan H. P. Pawestri. 2006. Implikasi Struktur Kepemilikan Terhadap Nilai Perusahaan: dengan Keputusan Keuangan sebagai Variabel Intervening. Simposium Nasional Akuntansi 9 Padang: 1-25

Toumi, K., Louhichi, W., \& Viviani, J.-L. (2015). Alternative Financial Decision Principles: Theoretical Foundations of Islamic Banks' Capital Structure. Recent Developments in Alternative Finance:Empirical Assessments and Economic Implications, 22(2012), 157-172

Walsh, Ciaran. 2004.Key Management Ratios : Rasio-rasio Manajemen Penting, Penggerak dan Pengendali Bisnis. terjemahan Shalahuddin Haikal. Penerbit : Erlangga, Jakarta.

Weston, J. F. dan E. F. Brigham. 1994. Dasar-dasar Manajemen Keuangan. Terjemahan Al Fonsus Sirait, Jilid 1, Edisi Kesembilan, Cetakan Pertama, Penerbit Erlangga, Jakarta.

Wijaya, L.R.P, Wibawa, A. 2010. Pengaruh Keputusan Investasi, Keputusan Pendanaan, Dan Kebijakan Dividen Terhadap Nilai Perusahaan. Simposium Nasional Akuntansi XIII Purwokerto.

www.indocashregister.com acsessed on 18 February 2019 